\title{
Proteomic and gene expression analyses during bolting-related leaf color change in Brassica rapa
}

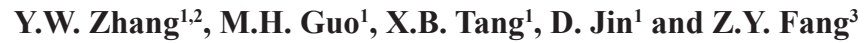

${ }^{1}$ College of Horticulture, Northeast Agricultural University, Harbin, China

${ }^{2}$ Key Laboratory of Biology and Genetic Improvement of Horticultural Crops (Northeast Region), Ministry of Agriculture, Harbin, China

${ }^{3}$ Institute of Vegetables and Flowers, Chinese Academy of Agricultural Sciences, Beijing, China

Corresponding author: Y.W. Zhang

E-mail: zhangyaowei@neau.edu.cn

Genet. Mol. Res. 15 (3): gmr. 15038584

Received February 29, 2016

Accepted April 11, 2016

Published August 12, 2016

DOI http://dx.doi.org/10.4238/gmr.15038584

Copyright (C 2016 The Authors. This is an open-access article distributed under the terms of the Creative Commons Attribution ShareAlike (CC BY-SA) 4.0 License.

\begin{abstract}
Bolting and flowering are key processes during the growth and development of Chinese cabbage (Brassica rapa L. ssp pekinensis). Understanding the molecular mechanisms underlying bolting and flowering is of significance for improving production of the vegetable. A leaf-color change from bright green to gray-green has been observed following differentiation of the flowering stem and before bolting in the vegetable, and is considered to be a signal for bolting. Proteomics in meristem tissues of an inbred line (C30) were analyzed by two-dimensional electrophoresis during the transition period. We found that some proteins were specifically expressed while others were differentially expressed. Among these, 17 proteins were specifically expressed before the color change, 18 were specifically
\end{abstract}


expressed after the color change, 21 were downregulated during the color change, and 29 were upregulated. Mass spectrometric analysis (MALDI-TOF-TOF/MS) was used to analyze 17 protein spots, and four proteins (subunit E1 of vacuolar-type $\mathrm{H}^{+}$transporter ATPase, the large subunit of Rubicon, S-adenosylmethionine synthetase, and tubulin $\alpha-2$ ) were identified. qPCR analysis was conducted to quantify the expression of genes encoding these proteins during the transitional period. The expression of BrVHA-E1, BrSAMS, BrrbcL, and $B r T U A 6$ was significantly different before and after the leaf-color change, suggesting that these genes might be involved in regulating flower differentiation and bolting.

Key words: Chinese cabbage; Bolting; Leaf color; Protein; Gene expression

\section{INTRODUCTION}

Chinese cabbage (Brassica rapa $\mathrm{L}$. ssp pekinensis) is one of the most important cruciferous vegetables. Bolting has evolved as an important developmental stage for brassica plants. Under certain light regimes, the cabbage changes from vegetative to reproductive growth after going through vernalization. The biology of flowering and bolting biology has been extensively studied at the molecular level in both Chinese cabbage and Arabidopsis thaliana. However, most of these studies have focused on the analysis of quantitative trait loci, regulatory pathways, and gene networks (Lin et al., 2005; Greenup et al., 2009; Turnbull, 2011; Wang et al., 2014; Blümel et al., 2015; Chung et al., 2015; Tao et al., 2015; Zhang et al., 2015, 2016), and the proteomics of bolting and flowering are poorly understood.

Two proteins in Chinese cabbage were found to be specifically expressed at the bolting stage (Ao and Li, 1997). Vernalization induced the production of a $58-\mathrm{kD}$ protein and the loss of another protein, possibly due to the expression of vernalization-related genes or the metabolism of DNA or proteins (Li et al., 2007). Three significantly enhanced bands were observed on SDS-PAGE during the analysis of soluble proteins extracted from Brassica oleracea at the bolting stage, with molecular weights of $48.4,18.8$, and $14.5 \mathrm{kD}$, while an 80.4-kD protein was lost (Yang et al., 2009).

In a previous study, we found that leaf color changed from bright green to graygreen before bolting in vernalized Chinese cabbage, which was followed by elongation of the flowering stem. The color change was most marked in the early flowering cultivars. When observed under a microscope, the meristem can be seen to protrude to form the flower, followed quickly by color change if the plant is grown under normal conditions. We have demonstrated that the leaf-color change is associated with changes in the levels of hormones, pigments, and proteins. The ratio of chlorophyll $\mathrm{a} / \mathrm{b}$ and levels of IAA (indole3-acetic acid) and GA3 (gibberellin A3) peaked at the point of the color change (Han et al., 2011). In the present study, we aimed to investigate the proteomics in the meristem tissues between the color change stages in order to better understand the developmental biology and molecular regulatory mechanisms underlying flowering and bolting in the Chinese cabbage.

Genetics and Molecular Research 15 (3): gmr.15038584 


\section{MATERIAL AND METHODS}

\section{Materials}

An inbred line of Chinese cabbage (C30), developed at Northeast Agricultural University, was seeded in $8 \times 8-\mathrm{cm}$ pots containing nutrient-rich soil. The seedlings were subjected to vernalization in a light incubator after the cotyledons were fully laid open at $8^{\circ} / 3^{\circ} \mathrm{C}$ (day/night) with a 16/8-h light/dark period for 25 days. The vernalized plants were transplanted to the field for normal growth. The differentiation of flower buds was confirmed by microscopy (Figure S1). When the color of the new leaf (which was about $1 \mathrm{~cm}$ in size) changed from bright green to gray-green (Figure 1), leaves smaller than $1 \mathrm{~cm}$ and their surrounding meristem tissues were collected and flash-frozen in liquid nitrogen for subsequent use.
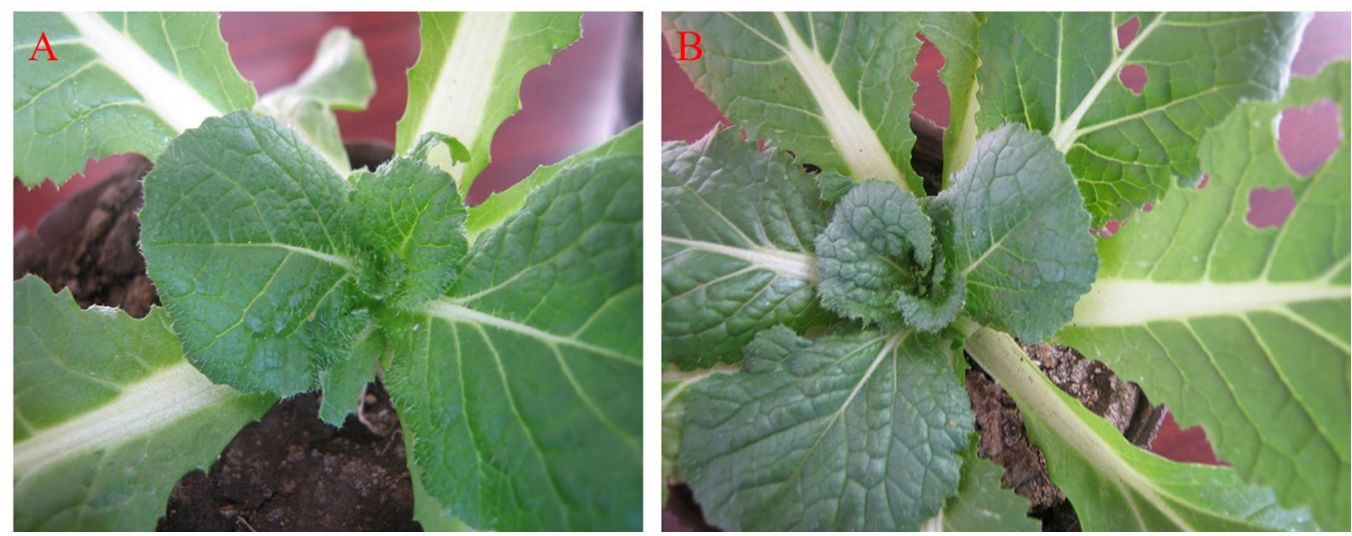

Figure 1. Leaf color change during bolting in Chinese cabbage. Leaf color before (A), and leaf color after (B) bolting.

\section{Protein extraction}

Proteins were extracted as previously described (Shao et al., 2009), with some modifications. Briefly, frozen tissue ( $1 \mathrm{~g})$ was ground to a fine powder in liquid nitrogen, added to pre-chilled TCA (trichloroacetic acid) ( $7 \mathrm{~mL}$ containing $0.07 \% \beta$-mercaptoethanol), vortexed, and incubated overnight at $-20^{\circ} \mathrm{C}$. The mixture was centrifuged at $15,000 \mathrm{~g}$ at $4^{\circ} \mathrm{C}$ for $30 \mathrm{~min}$, and the pellet was resuspended in ice-cold acetone ( $7 \mathrm{~mL}$ containing $0.07 \% \beta$-mercaptoethanol), vortexed periodically, and incubated at $-20^{\circ} \mathrm{C}$ for $2 \mathrm{~h}$. The procedure was repeated and the pellets were vacuum-dried. For protein extraction, $1 \mathrm{mg}$ of the pellet was suspended in 10-20 $\mu \mathrm{L}$ lysis buffer $[7.0 \mathrm{M}$ urea, $2.0 \mathrm{M}$ thiourea, $4 \%(\mathrm{w} / \mathrm{v})$ CHAPS, $60 \mathrm{M}$ DTT, and $0.5 \%(\mathrm{v} / \mathrm{v})$ IPG buffer], and incubated in a water bath at $35^{\circ} \mathrm{C}$ for $2 \mathrm{~h}$ or freeze-thawed three times (with full vortex). The extraction was centrifuged as described above and the protein content in the supernatant was quantified using the Bradford method (Kruger, 1994).

\section{Two-dimensional gel electrophoresis}

The proteins were analyzed using two-dimensional gel electrophoresis as previously

Genetics and Molecular Research 15 (3): gmr.15038584 
described (Liu et al., 2009), with some modifications. Protein $(200 \mu \mathrm{g})$ in loading buffer [7.0 M urea, 2.0 M thiourea, 4\% (w/v) CHAPS, $60 \mathrm{M} \mathrm{DTT,} \mathrm{and} \mathrm{0.5 \%} \mathrm{(v/v)} \mathrm{IPG} \mathrm{buffer]} \mathrm{was}$ loaded and analyzed on an Isoelectric Focusing System IPGPhor II ${ }^{\mathrm{TM}}$ using a 24-cm strip at $\mathrm{pH} 4-7$, according to the manufacturer instructions. Electrophoresis was performed at $20^{\circ} \mathrm{C}$ after hydration at $50 \mathrm{~V}$ for $12 \mathrm{~h}$, followed by $500 \mathrm{~V}$ for $1 \mathrm{~h}, 1000 \mathrm{~V}$ for $1 \mathrm{~h}, 1000-8000 \mathrm{~V}$ for $1 \mathrm{~h}, 8000 \mathrm{~V}$ for $10 \mathrm{~h}$, and $500 \mathrm{~V}$ for $10 \mathrm{~h}$. The second SDS-PAGE was performed on an Ettan DALTsix Electrophoresis System at $18^{\circ} \mathrm{C}$ with a $10 \mathrm{~mA}$ initial current and a $20 \mathrm{mM}$ resolution current applied when the samples were moved out of the IPG strips. The proteins were visualized by silver staining for $30 \mathrm{~min}$. Each assay was repeated three times.

\section{Gel chromatogram analysis}

The stained gels were scanned using a 24-color or gray scale with an Imagescan (Amersham) at a resolution of 600 dpi with default brightness and contrast settings. The chromatograms were analyzed using the ImageMaster ${ }^{\mathrm{TM}}$ 2D Platinum software (Version 5.0, Amersham) in order to determine the number of protein spots, optical density, area, and volume. The protein abundance was determined before and after the leaf-color change, and proteins were identified as being differentially expressed if the difference in their abundance was greater than 3-fold.

\section{Mass spectrometry and homology search}

Spots that were differentially expressed were isolated for mass spectrometry analysis as previously described (Chen et al., 2009) at the Proteome Research Center (Huada Inc., Beijing, China) using a 4700 Proteomics Analyzer (Applied Biosystems, USA). The peptide mass fingerprints were analyzed using Mascot (http://www.matrixscience.com). Protein homologs were searched on the NCBI, MSDB, and EST-Viridiplantae databases. To ensure reliability, each protein was sequenced for at least $15 \%$ of the total predicted protein using a minimum of five peptide fragments with less than 1 Dalton mass error and at least one unhydrated restriction site.

\section{RNA extraction and $q P C R$}

Expression and analysis of the proteins selected in this study were based on a Mascot database search with a limit score of 70 , the tested spots whose molecular weights and isoelectric points were close to related species. Total RNA was extracted from leaf and meristem tissue samples using the TRIzol method. First-strand cDNA was synthesized using RevertAid First-Strand cDNA Synthesis Kit (TransGen Biotech Co., Ltd., Beijing, China) according to the manufacturer instructions in a $20-\mu \mathrm{L}$ reaction volume containing $4 \mu \mathrm{L}$ total RNA. Primers were designed based on the DNA sequences identified from the Brassica genome database (http://brassicadb.org) using DNAMAN 6.0. Genes and their specific primers used for qPCR included $B r V H A$-E1, forward 5'-GGCAAGATTATGAGAAGA-3', reverse 5'-ATGGCATTG ACAATATCA-3'; BrrbcL, forward 5'-GGAGTTCCTATCGTAATG-3', reverse 5'-CCATGAT TCTTCTGTCTAT-3'; $\quad B r S A M S, \quad$ forward 5'-TATAGTCCAAGTGTCGTA-3', reverse 5'-CAAGGTTAATAGCCATCA-3'; and BrTUA6, forward 5'-TTGTATGATCTCCAACTC-3', reverse 5'-CAACCTCTTCATAATCCT-3'. The primers were synthetized at Beijing Genomics

Genetics and Molecular Research 15 (3): gmr.15038584 
Institution. The efficiency of the primers used in this study was at least 96\%. qPCR was performed using a TransStart ${ }^{\mathrm{TM}}$ Top Green qPCR SuperMix kit (TransGen Biotech Co., Ltd.) with four replicates. Real-time PCR assays were performed on a Biorad iQ5 real-time PCR detector system (Bio-Rad). qPCR conditions were as follows: pre-denaturation at $95^{\circ} \mathrm{C}$ for $3 \mathrm{~min}$, followed by 40 cycles of denaturation at $95^{\circ} \mathrm{C}$ for $20 \mathrm{~s}$, annealing at $50^{\circ} \mathrm{C}$ for $30 \mathrm{~s}$, and extension at $72^{\circ} \mathrm{C}$ for $30 \mathrm{~s}$. Melting curve analysis was completed following amplification. The GAPDH gene was used as an endogenous quantification control.

\section{RESULTS}

\section{Proteomic analyses}

Electrophoresis experiments were performed in triplicate using the same experimental conditions and parameters, with soluble proteins obtained before and after the leaf-color change, from the inbreeding line C30. Soluble proteins extracted from plant tissues were wellseparated on SDS-PAGE after two-dimensional electrophoresis. After silver staining, clear protein spots were visible with uniform distribution, excellent resolution, and repeatability. Representative images of the samples before and after the leaf-color change are shown in Figure 2. The samples contained similar species and amounts of proteins before and after the color change, indicating that most of the proteins were stable during that period. There were some stage-specific proteins with isoelectric points between 4.5 and 7.0, and molecular weights between 13 and $74 \mathrm{kD}$. The number of protein spots detected was 1126 and 1147 before and after the color change, respectively.

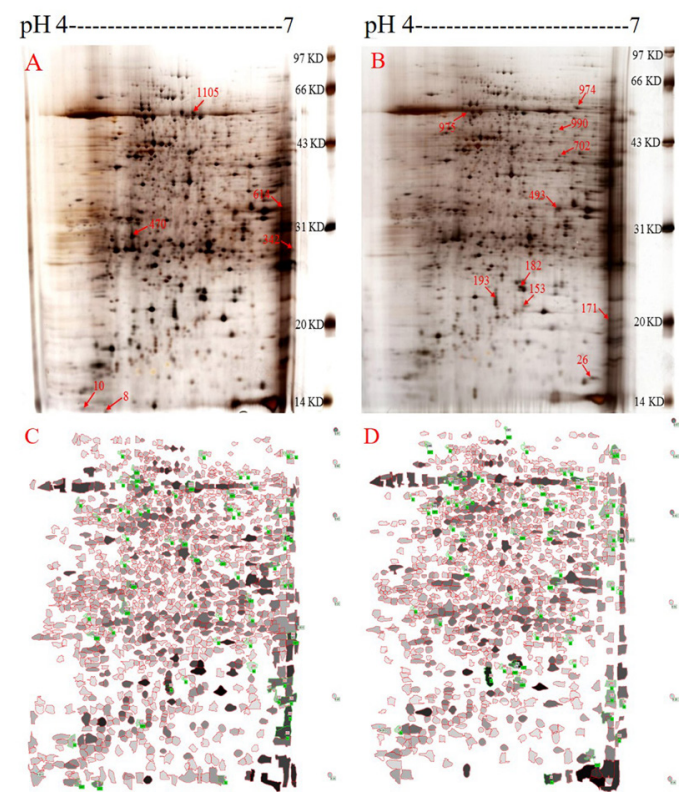

Figure 2. Two-dimensional SDS-PAGE showing protein dynamics in Chinese cabbage. Protein dynamics before the leaf-color change (A), protein dynamics after the leaf-color change (B). Analogue results before the leaf-color change $(\mathbf{C})$, and analogue results after the leaf-color change (D).

Genetics and Molecular Research 15 (3): gmr.15038584 
Eighty-five proteins with changes in expression of 3-fold or more during the color change period were identified after analysis with the PDQuest software. Of these, 17 proteins were specifically expressed before the color change, 18 were specifically expressed after the change, 21 were downregulated during the change, and 29 were upregulated.

\section{Mass spectrometric analysis and protein homology search}

Five differentially expressed proteins with at least a 3-fold change in expression, and 12 specifically expressed proteins were selected for mass spectrometric analysis. The reproducibility and abundance of these proteins were confirmed. They were easily distinguished from other protein spots and were easily isolated. The protein spots were identified only when the Mascot Protein Scores were greater than $50(\mathrm{P}<0.05)$. Among the 17 proteins, 16 were identified in a MASCOT database search, and most presented some differences between the predicted and actual molecular weights and isoelectric points. Five of those (spots number 470, 493, 975, 974, and 990) had similar predicted and actual molecular weights and isoelectric points. Spots 974 and 493 were the same protein (RuBisCO large subunit). Spot 702, one of the identified proteins, was an unknown protein. Spots 10, 26, 153, 171, and 342 were hypothetical proteins. The other proteins were possibly involved in transcriptional regulation, signal and energy transduction, growth, and metabolism, or were structural proteins (Table 1). Based on the Mascot scores (Figure S2), proteins on spots 470, 493, 975, and 990 were most homologous to $A$. thaliana subunit $\mathrm{E}$ of vacuolar-type $\mathrm{H}^{+}$transporter ATPase, the large subunit of Brassica RuBisCO, A. thaliana S-adenosylmethionine synthetase, and canola tubulin $\alpha-2$, respectively.

\section{Expression of the four identified genes}

Amino acid sequences were used to search the Brassica genome database (http:// brassicadb.org); Bra033155, Bra028087, Bra023084, and Bra018825 were highly homologous with the identified proteins. These clones were designated BrVHA-E1, $B r r b c L, B r T U A 6$, and $B r S A M S$, respectively, and their expression was analyzed by qPCR using mRNA extracted from leafs before and after the color change. BrTUA6, BrrbcL, and $B r S A M S$ were upregulated after the color change, while BrWHA-E1 was downregulated (Figure 3). In the two-dimensional protein analysis, the proteins on spots 975 and 493, which corresponded to BrTUA6 and BrrbcL, respectively, were expressed only after the color change, while the protein on spot 470 , which corresponded to BrVHA-E1, was only expressed before the color change. The protein coded by BrSAMS was upregulated after the color change. These data indicated that the protein and gene expression results were consistent based on the protein analysis and qPCR results. However, the levels of BrrbcL and BrVHA-E1 expression, but not of BrSAMS and BrTUA6, differed significantly ( $\mathrm{P}<$ $0.05)$ before and after the leaf-color change. Further studies are required to analyze the expression profiles.

\section{DISCUSSION}

Bolting is a complex physiological and biochemical process in Chinese cabbage, which involves the participation of many genes. The dynamics of protein expression during

Genetics and Molecular Research 15 (3): gmr.15038584 
Proteomic analyses during bolting in Brassica rapa

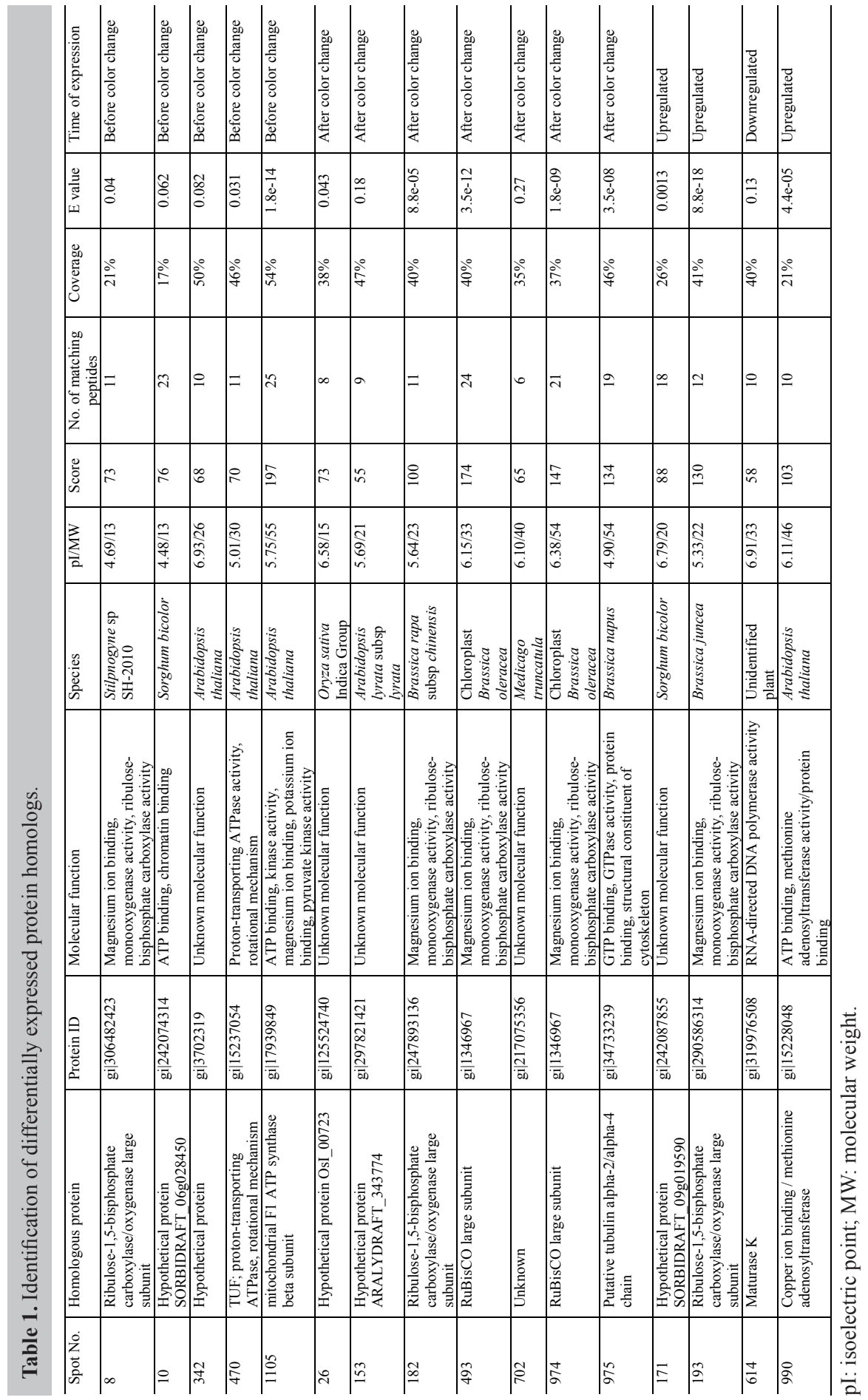

Genetics and Molecular Research 15 (3): gmr.15038584 


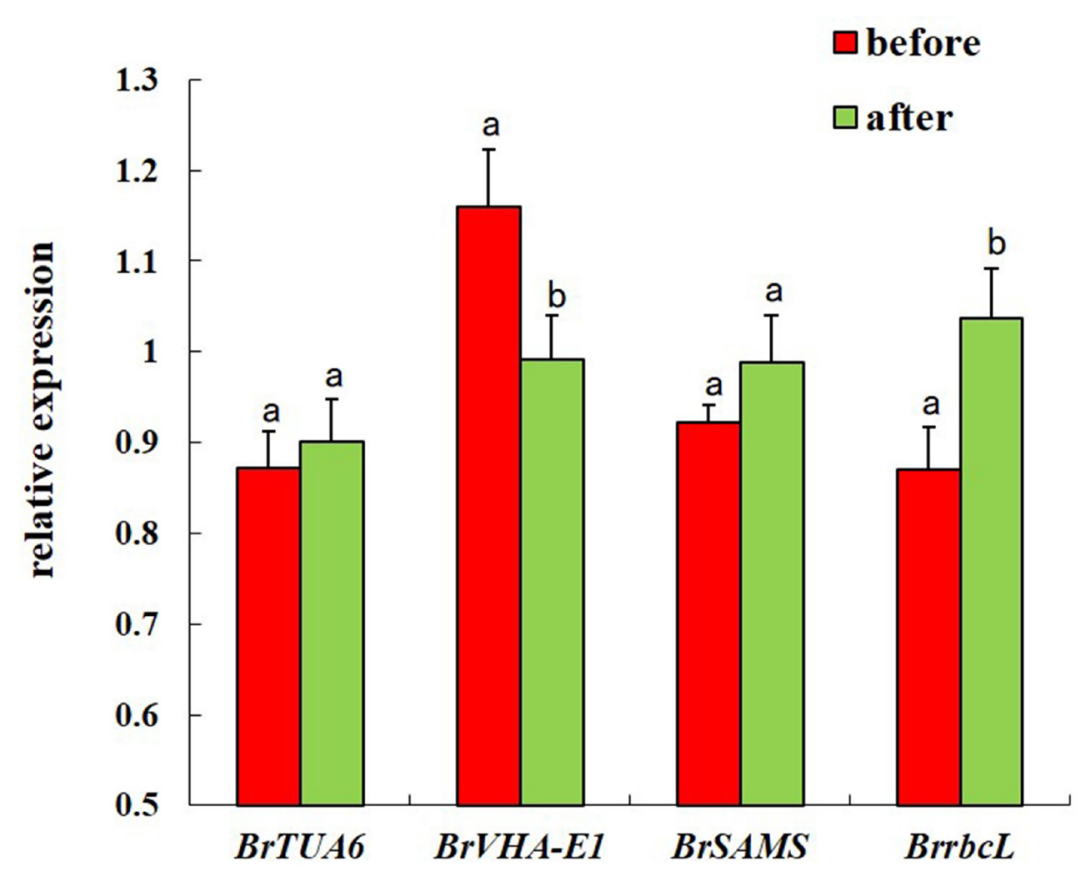

Figure 3. Expression of four genes encoding differentially expressed proteins before and after leaf color change. The internal control gene is GAPDH, a and b above the bars are significant differences, same letters mean nonsignificant differences.

the bolting stage can be visualized using two-dimensional SDS-PAGE. In this study, 1126 and 1147 protein spots were detected before and after the leaf-color change, respectively. Only 85 protein spots that quantitatively or qualitatively changed during the bolting stage were associated with the color change. The levels of specific and differential proteins were low, probably because the two processes were sampled over a small time period. These proteins might be involved in transcriptional regulation, signal and energy transduction, cell growth and metabolism, or they could be structural proteins. It is likely that they are involved in the bolting process.

S-adenosylmethionine synthetase (SAMS) is a key enzyme involved in plant metabolism, which catalyzes the synthesis of S-adenosylmethionine (SAM) from methionine and ATP. SAMS is the precursor of ethylene and polyamine, which are regulators of development and stress resistance in many plants. SAMS is more highly expressed in the stems than in the leaves of $A$. thaliana and is localized to vascular tissue (Peleman et al., 1989). In carnation flower tissues, the expression of SAM decreases as the flowers blossom (Woodson et al., 1992). In the present experiment, the SAMS protein was upregulated following the color change, suggesting that it may be involved in the regulation of bolting. However, the level of $B r S A M S$ expression was not significantly different $(\mathrm{P}<0.05)$ before and after the leafcolor change. We speculated that homologues of BrSAMS might exist in the Chinese cabbage genome. We found three BrSAMS genes in a Brassica genome database using bioinformatic analysis. Further study is needed to analyze the expression profiles of these genes.

Genetics and Molecular Research 15 (3): gmr.15038584 
Microtubules exist widely in the cytoskeleton, and are important for cellular morphology, cell division, transportation, energy transfer, and signal transduction, and $\alpha$-tubulin is the basic unit of microtubules. Genes encoding different isomers of the protein are differentially expressed in different tissues and development stages. A number of studies have been conducted on plant tubulins (Carpenter et al., 1992; Uribe et al., 1998; Xu et al., 1999; Li et al., 2007). Transgenic expression of GFP-TUA6 revealed that transverse microtubules form during the elongation stage of the inner cell wall in A. thaliana (Chan et al., 2011). Microtubules on the outer cell wall are changeable, and tend to arrange transversally during the period of fastest growth. The arrangement of microtubules on the walls of the outer epidermal cells affects the rate at which the cells elongate. We found that BrTUA6 proteins were expressed specifically after the leafcolor change, suggesting that changes in the arrangement of microtubules might occur in order to prepare for the elongation of flowering stems and bolting. However, levels of BrTUA6 expression were not significantly different before and after the leaf-color change. Twelve $\alpha$-tubulin genes have been identified in a Brassica genome database. Bioinformatic analysis revealed that Bra018825 (BrTUA6) shares 93.4\% homology with Bra039648 (BrTUA6) at the nucleic acid level, and their deduced amino acid sequences are identical. Furthermore, their expression levels were not significantly different, possibly because TUA has multiple homologous genes, and the primers used for qPCR analysis are not nonspecific. Further study is needed to gain a better understanding of the genomic structure of BrTUA6.

Vacuoles act as reservoirs of ions and metabolites in higher plant cells. V-ATPase is a highly conserved proton pump found on vacuolar membranes, which regulates the movement, metabolism, and transportation of vacuolar proteins through the acidification of organelle lumens. This enzyme possesses multiple subunits and is involved in the regulation of a number of cell growth and metabolic processes (Matsuoka et al., 1997; Schumacher et al., 1999; Seidel et al., 2008). In the present study, we found that BrVHA-E1 was only expressed before the leaf-color change using two-dimensional SDS-PAGE and was found to be significantly downregulated after the leaf-color change. It is possible that BrVHA-E1 is only associated with the differentiation of flower buds. This result is consistent with a previous report stating that VHA-E1 is involved in regulating early embryogenesis in $A$. thaliana (Strompen et al., 2005).

Ribulose-1,5-bisphosphate carboxylase oxygenase, or RuBisCO, is the key enzyme involved in the Calvin cycle of carbon assimilation during photosynthesis. RuBisCO is made up of eight small subunits and eight large subunits, in which its active centers are located. Moreover, the Calvin cycle is the fundamental pathway of carbon assimilation to synthesize starch, sucrose, and other products. The activity of enzymes in this pathway directly determines the net photosynthetic yield. Kraus and Kraybill (1918) proposed that increases in the $\mathrm{C} / \mathrm{N}$ ratio would cause plants to flower. Conversely, sucrose signal transduction regulates the expression of a large number of genes, and thereby influences a variety of important physiological and developmental processes. For example, sucrose has been found to directly regulate the expression of the flower regulator LFY (LEAFY) (Blazquez et al., 1998; Ohto et al., 2001) and is therefore important for regulating flowering in plants. In our study, we found that some large RuBisCO subunits were specifically expressed or upregulated after the leaf-color change. In addition, BrrbcL was more highly expressed after the color change than before the color change, suggesting that the assimilation efficiency might increase after the color change. The increase would boost the synthesis of photosynthetic products, leading to an increased $\mathrm{C} / \mathrm{N}$ ratio, and the subsequent occurrence of bolting and flowering in the plant.

Microtubules are ubiquitous structures in the cytoskeleton, which contain $\alpha$-tubulin as

Genetics and Molecular Research 15 (3): gmr.15038584 
the basic unit. Different isomers of $\alpha$-tubulin protein encoding genes have different expression patterns during specific developmental stages or in the cells of specific tissues (Carpenter et al., 1992; Xu et al., 1999; Li et al., 2007). In the present study, we observed differential expression of $\alpha$-tubulin during the process of leaf-color change, although BrTUA6 was not differentially expressed. These results suggest that variation in microtubule arrangement could be associated with floral axis elongation and bolting following leaf color change. Therefore, we could predict and identify cis-acting elements in the promoter sequences of BrTUAs, and the expression of different genes. The bolting process could be controlled by regulating the expression of BrTUAs, on account of BrTUAs containing cis-elements that are responsive to light, temperature, hormonal signals, and tubulin-specific drugs. The same controls could be used for BrSAMS. Based on a Mascot search, only four spots were verified with molecular weights and isoelectric points that were close to those of related species. However, the other spots had different molecular weights and isoelectric points, and might contain additional information.

\section{Conflicts of interest}

The authors declare no conflict of interest.

\section{ACKNOWLEDGMENTS}

Research supported by the Foundation for Key Technologies R\&D Program (\#2012BAD02B01-13).

\section{REFERENCES}

Ao YS and Li SJ (1997). Change of soluble proteins during development of chinese cabbage Brassica rapa $\mathrm{ssp}$. Pekinensis. China Veget. 2: 19-21.

Blazquez MA, Green R, Nilsson O, Sussman MR, et al. (1998). Gibberellins promote flowering of Arabidopsis by activating the LEAFYpromoter. Plant Cell 10: 791-800. http://dx.doi.org/10.1105/tpc.10.5.791

Blümel M, Dally N and Jung C (2015). Flowering time regulation in crops - what did we learn from Arabidopsis? Cur. Opin. Biotechnol. 32: 121-129. http://dx.doi.org/10.1016/j.copbio.2014.11.023

Carpenter JL, Ploense SE, Snustad DP and Silflow CD (1992). Preferential expression of an alpha-tubulin gene of Arabidopsis in pollen. Plant Cell 4: 557-571.

Chan J, Eder M, Crowell EF, Hampson J, et al. (2011). Microtubules and CESA tracks at the inner epidermal wall align independently of those on the outer wall of light-grown Arabidopsis hypocotyls. J. Cell Sci. 124: 1088-1094 http:// dx.doi.org/10.1242/jcs. 086702

Chen RH, Ye JX, Zhang GS, JC Zhu (2009). Differential Proteomic Analysis of Anther Proteins Between CytoplasmicNuclear Male Sterility Line and Its Maintainer in Wheat (Triticum aestivum L.). Prog. Bioch. Bio. 36: 431-440.

Chung JS, Lee HN, Leustek T, Knaff DB, et al. (2015). The Arabidopsis thaliana adenosine 5'-phosphosulfate reductase 2 (AtAPR2) participates in flowering time and glucose response. J. Plant Bio. 58: 128-136. http://dx.doi.org/10.1007/ $\underline{\text { s12374-014-0514-2 }}$

Greenup A, Peacock WJ, Dennis ES and Trevaskis B (2009). The molecular biology of seasonal flowering-responses in Arabidopsis and the cereals. Ann. Bot. 103: 1165-1172. http://dx.doi.org/10.1093/aob/mcp063

Han DP, Li CG and Zhang YW (2011). Physiological changes before and after leaf color change in the bolting process of Chinese cabbage. China Veget. 20: 34-38.

Kraus EJ and Kraybill HR (1918). Vegetation and reproduction with special reference to the tomato. Ore. Agric. Exp. Stn. Bull. 149: 1-90.

Kruger NJ (1994). The Bradford method for protein quantitation. Basic protein and peptide protocols, 9-15.

Li L, Wang XL, Huang GQ and Li XB (2007). Molecular characterization of cotton GhTUA9 gene specifically expressed

Genetics and Molecular Research 15 (3): gmr.15038584 
in fibre and involved in cell elongation. J. Exp. Bot. 58: 3227-3238. http://dx.doi.org/10.1093/jxb/erm167

Lin SI, Wang JG, Poon SY, Su CL, et al. (2005). Differential regulation of FLOWERING LOCUS C expression by vernalization in cabbage and Arabidopsis. Plant Physiol. 137: 1037-1048. http://dx.doi.org/10.1104/pp.104.058974

Liu HH, Hu SW, Liu SY, Huang JY, et al. (2009). Optimization of high quality total protein extraction and two-dimensional gel electrophoresis system for different Brassica napus organs. Chin. J. Oil Crop Sci. 31: 426-433.

Matsuoka K, Higuchi T, Maeshima M and Nakamura K (1997). A Vacuolar-Type H-ATPase in a Nonvacuolar Organelle Is Required for the Sorting of Soluble Vacuolar Protein Precursors in Tobacco Cells. Plant Cell 9: 533-546.

Ohto M, Onai K, Furukawa Y, Aoki E, et al. (2001). Effects of sugar on vegetative development and floral transition in Arabidopsis. Plant Physiol. 127: 252-261. http://dx.doi.org/10.1104/pp.127.1.252

Peleman J, Boerjan W, Engler G, Seurinck J, et al. (1989). Strong cellular preference in the expression of a housekeeping gene of Arabidopsis thaliana encoding S-adenosylmethionine synthetase. Plant Cell. 1: 81-93. http://dx.doi. org $/ 10.1105 /$ tpc.1.1.81

Schumacher K, Vafeados D, McCarthy M, Sze H, et al. (1999). The Arabidopsis det3 mutant reveals a central role for the vacuolar $\mathrm{H}^{+}$-ATPase in plant growth and development. Genes Dev. 13: 3259-3270. http://dx.doi.org/10.1101/ gad.13.24.3259

Seidel T, Schnitzer D, Golldack D, Sauer M, et al. (2008). Organelle-specific isoenzymes of plant V-ATPase as revealed by in vivo-FRET analysis. BMC Cell Biol. 9: 28. http://dx.doi.org/10.1186/1471-2121-9-28

Shao CH, Xie JS, Huang YL, QIU CF, et al. (2009). Developmental proteomics analysis of different functional leaves in rice (Oryza sativa) at the booting stage. Chin. J. Rice Sci. 23: 456-462.

Strompen G, Dettmer J, Stierhof YD, Schumacher K, et al. (2005). Arabidopsis vacuolar H-ATPase subunit E isoform 1 is required for Golgi organization and vacuole function in embryogenesis. Plant J. 41: 125-132. http://dx.doi. org/10.1111/j.1365-313X.2004.02283.X

Tao L, Wang XL, Guo MH and Zhang YW (2015). Analysis of genomic DNA methylation and gene expression in Chinese cabbage (Brassica rapa L. ssp. pekinensis) after continuous seedling breeding. Genetika 51: 905-914. http://dx.doi. org/10.7868/S0016675815080111

Turnbull C (2011). Long-distance regulation of flowering time. J. Exp. Bot. 62: 4399-4413. http://dx.doi.org/10.1093/jxb/ $\underline{\operatorname{err} 191}$

Uribe X, Torres MA, Capellades M, Puigdomenech P, et al. (1998). Maize alpha-tubulin genes are expressed according to specific patterns of cell differentiation. Plant Mol. Biol. 37: 1069-1078. http://dx.doi.org/10.1023/A:1006067710312

Wang YG, Zhang L, Ji XH, Yan JF, et al. (2014). Mapping of quantitative trait loci for the bolting trait in Brassica rapa under vernalizing conditions. Genet. Mol. Res. 13: 3927-3939. http://dx.doi.org/10.4238/2014.May.23.3

Woodson WR, Park KY, Drory A, Larsen, et al. (1992). Expression of ethylene biosynthetic pathway transcripts in senescing carnation flowers. Plant Physiol. 99: 526-532. http://dx.doi.org/10.1104/pp.99.2.526

Xu L, Zheng WZ and Zuo ZH (1999). Progress in molecular biological studies of $\alpha$-Tubulin in maize. Chin. B. Bot. 16: 488-494.

Yang XM, Li CQ, Song HY, et al. (2009). The changes of physiological and biochemical in spring cabbage differentiation of flower bud to bolting period. China Veget. 24: 19-23.

Zhang XM, Meng L, Liu B, Hu Y, et al. (2015). A transposon insertion in FLOWERING LOCUS T is associated with delayed flowering in Brassica rapa. Plant Sci. 241: 211-220. http://dx.doi.org/10.1016/j.plantsci.2015.10.007

Zhang YW, Jin D, Xu C, Zhang L, et al. (2016). Regulation of bolting and identification of the $\alpha$-tubulin gene family in Brassica rapa L. ssp pekinensis. Genet. Mol. Res. 15: doi: http://dx.doi.org/10.4238/gmr.15017507.

\section{Supplementary material}

Figure S1. Differentiation of flower buds was confirmed by microscopy. Vegetative growth phase (A), flower bud differentiation (B), complete flower bud differentiation (C).

Figure S2. Spectra of differential protein generated by the MALDI-TOF-TOF/MS (matrix-assisted laser desorption/ ionization time-of-flight/time-of-fligh mass spectrometer). No. 470 (A), No. 493 (B), No. 990 (C), and No. 975 (D).

Genetics and Molecular Research 15 (3): gmr.15038584 